\title{
Creysse - Les Rivelles
}

$n^{\circ} 026009$

\section{Milagros Folgado-Lopez}

\section{(2) OpenEdition}

\section{Journals}

Édition électronique

URL : http://journals.openedition.org/adlfi/16375

ISSN : 2114-0502

Éditeur

Ministère de la culture

Référence électronique

Milagros Folgado-Lopez, "Creysse - Les Rivelles », ADLFI. Archéologie de la France - Informations [En ligne], Aquitaine, mis en ligne le 10 février 2016, consulté le 19 avril 2019. URL : http:// journals.openedition.org/adlfi/16375

Ce document a été généré automatiquement le 19 avril 2019

(c) Ministère de la Culture et de la Communication, CNRS 


\title{
Creysse - Les Rivelles
}

\author{
$n^{\circ} 026009$
}

\section{Milagros Folgado-Lopez}

Lien Atlas (MCC) :

http://atlas.patrimoines.culture.fr/atlas/trunk/index.php?

ap_theme=DOM_2.01.02\&ap_bbox=0.527;44.844;0.584;44.887

1 Un diagnostic archéologique a été réalisé au lieu-dit les Rivelles. À l'origine, $4057 \mathrm{~m}^{2}$ devaient être diagnostiqués. Cette surface a été réduite à environ $3130 \mathrm{~m}^{2} \mathrm{du}$ fait de travaux de terrassement divers déjà opérés sur la parcelle.

2 Les 169 pièces lithiques prélevées (en silex bergeracois) se repartissent de manière très inégale sur les secteurs évalués. Dans les sondages 1 et 2 , sept pièces sont attribuables au Paléolithique moyen au sens large. Dans le sondage 3, 162 pièces (probablement de période Holocène) ont été prélevées, mais aucun marqueur typo-technologique - nucléus ou outil - n'a été identifié.

3 La présence d'artefacts lithiques attribués au Paléolithique et au Néolithique est une constante dans ce secteur des Rivelles sur le plateau du Pecharmant. Les conditions de mise en place et de conservation du matériel sont, de surcroît, assez proches sur l'ensemble des parcelles diagnostiquées précédemment. Toutefois, dans la parcelle qui a été ici évaluée, aucun niveau conséquent attribuable au Paléolithique ou au Néolithique n'a été constaté. 
INDEX

Index chronologique : Paléolithique, Néolithique

Index géographique : Aquitaine, Dordogne (24), Creysse

operation Opération préventive de diagnostic (OPD)

Mots-clés : silex

\section{AUTEURS}

\section{MILAGROS FOLGADO-LOPEZ}

Inrap 